\title{
Opening Speech by Chairman of ISOCEEN 2017 for International Seminar on Ocean and Coastal Engineering, Environmental and Natural Disaster Management, on Tuesday, 08 November, 2017 at 08.45 am at Swiss Bellin Manyar Hotel, Surabaya
}

The first that we respect, Rector of ITS, Prof. Joni Hermana, Head of Ocean Engineering Department, Dr.Eng. Rudi Walujo P, Keynote Speaker, Dr. Alvaro Semedo, Dr. Ali Dastgheib, from Unesco-IHE, Netherlands, Invited talks Dr. Mohd Faris Khamidi, University of Reading Malaysia, Liliane Geerling, R.TD, HZ University of Applied Sciences-Delta Academy, Netherlands, Lecturers within ITS, Contributing Authors, Seminar delegates, experts, scholar, all student, Ladies and gentlemen.

Assalamu alaikum Wr. Wb., Good morning! Presence of Allah SWT 's grace that has given favors and gifts in this morning. Welcome to this The $5^{\text {th }}$ International Seminar on Ocean and Coastal Engineering, Environmental and Natural Disaster Management (ISOCEEN 2017). I am pleased to join you here today.

We are delighted to announce that Institut Teknologi Sepuluh Nopember (ITS) especially Department of Ocean Engineering and Tohoku University have collaboration since 1997. In which, in the year 2006, a Memorandum of Understanding (MoU) has been signed between Tohoku University, Japan and Institut Teknologi Sepuluh Nopember to promote further collaboration between two institutions and and it has been extended until 20 December 2016. Many activities that have performed well in term of collaborative research, faculty and student exchange, joint educational program, seminars, workshops etc, especially for the seminar and workshop has been done several times before, namely; Japan-Indonesia Estuary Workshop, August 22 $2^{\text {nd }}, 2005$ Jakarta, Japan - Indonesia Workshop on Estuary and Climate Change (JIWECC), August $8^{\text {th }}-10^{\text {th }}$ Surabaya, Indonesia. However the previous seminar activities organized not regularly therefore Since 2013 held an annual seminar entitled The first International Seminar on Ocean, Coastal Engineering, Environmental and Natural Disaster Management (ISOCEEN), November 11, 2013, Surabaya Indonesia.The $2^{\text {nd }}$ International Seminar on Ocean and Coastal Engineering, Environmental and Natural Disaster Management (ISOCEEN), December 2, 2014. In which the selected papers have been published to the International Journal, Procedia Earth and Planetary Science. http://www.sciencedirect.com/science/journal/18785220/14

The $3^{\text {rd }}$ ISOCEEN has been organized at 10 December 2015. The selected papers have been published to Trans Tech Publication on Applied Mechanics and Material Volume 862 in Special Edition Ocean Science and Coastal Engineering indexed in ISI Thomshon Rheuter.

Moreover, a Memorandum of Understanding (MoU) has been signed on July 29, 2015 between Institut Teknologi Sepuluh Nopember and HZ University of Applied Sciences, Netherlands to promote the development of academic scientific and cultural exchange, and of teaching and research activities, especially with Department of Ocean Engineering, ITS. And in 2016-2019 
Our Department also have grants from Nuffic-Niche Project to increase collaboration among ITS-ITB and TU Delft Consorsium, Netherlands.

The $4^{\text {th }}$ ISOCEEN has been organized at 13 December 2016. The selected papers have been published to to "IOP Conference Series: Earth and Environmental Science” indexed in Scopus. http://iopscience.iop.org/issue/1755-1315/135/1

With the increasing amount of cooperation between Indonesia, Japan, Netherlands and another country then this forum is more focused on creating and expanding professional network to foster the relationship between the University, industry, business and communities across the country. Therefore it is necessary to hold The $5^{\text {th }}$ International Seminar on Ocean and Coastal Engineering, Environmental and Natural Disaster Management (ISOCEEN) 2017 in which the selected papers presented in the seminar will be published to "MATEC Web of Conferences" indexed in Scopus.

Finaly, on behalf of the organizing committee of the seminar, sincere appreciation is expressed to all speakers contributing to our seminar. Special thanks are also due to all keynote speakers and all committee for the efforts in preparing the manuscripts and managing the sessions, respectively.

Wish the seminar a complete success.

Thank you ! 